\title{
Penggunaan google classroom sebagai pengembangan kelas virtual dalam keterampilan pemecahan masalah topik kinematika pada mahasiswa jurusan sistem komputer
}

\author{
Nia Maharani ${ }^{1 *}$, Ketut Sepdyana Kartini \\ STMIK STIKOM INDONESIA BALI \\ *Email: maharani.nst@gmail.com
}

DOI: https://doi.org/10.33369/pendipa.3.3.167-173

\begin{abstract}
[The use of google classroom as a virtual classroom development in problem solving skills on kinematics topics for students majoring in computer systems] From observations in the field, it appears that students basically experience obstacles in developing problem solving skills. To assist students in developing problem solving skills, we can use technology developments that are developing rapidly in the last decade. One way of it is use Google Classroom. Therefore this study aims to develop student problem solving skills in the topic of parabolic motion and test the effectiveness of Google Classroom in the learning process on parabolic motion material. The research method used is a qualitative description based development research. The study was conducted with pre-research stages, experiments, evaluation of written tests and questionnaires. The research subject is in one class majoring in computer systems using all subjects in the study group (intact group) to be given treatment. The research shows that the Use of Google Classroom was running optimally. This can be seen from the results of student work and the results of questionnaires filled out by students. Besides learning with Google Classroom has the effectiveness to support the problem solving skills of these students which can be seen from the results of the questionnaire.
\end{abstract}

Keywords: Information Technology; Google Classroom; Parabolic Motion; Problem Solving Skill.

(Received August 26, 2019; Accepted September 24, 2019; Published November 9, 2019)

\begin{abstract}
ABSTRAK
Dari hasil pengamatan di lapangan, terlihat bahwa mahasiswa pada dasarnya mengalami kendala dalam mengembangkan keterampilan pemecahan masalah. Untuk membantu mahasiswa dalam mengembangkan keterampilan pemecahan masalah, maka dapat digunakan perkembangan teknologi yang maju pesat saat ini. Salah satu caranya adalah menggunakan Google Classroom. Oleh sebab itu penelitian ini bertujuan untuk mengembangkan keterampilan pemecahan masalah mahasiswa dalam topik gerak parabola serta menguji efektivitas Google Classroom dalam proses pembelajaran pada materi gerak parabola. Metoda penelitian yang digunakan adalah penelitian pengembangan yang berbasis deskripsi kualitatif. Penelitian dilakukan dengan tahapan pra penelitian, eksperimen, evaluasi tes tertulis dan kuesioner. Subjek penelitian adalah pada satu kelas jurusan sistem komputer dengan menggunakan seluruh subjek dalam kelompok belajar (intact grup) untuk diberikan perlakuan (treatment). Hasil penelitian menunjukkan bahwa penggunaan Google Classroom berjalan secara optimal. Hal tersebut dapat dilihat dari hasil pekerjaan mahasiswa dan hasil kuesioner yang diisi oleh mahasiswa. Selain itu pembelajaran dengan Google Classroom memiliki efektivitas untuk menunjang keterampilan pemecahan masalah dari mahasiswa tersebut yang dapat dilihat dari hasil kuesioner.
\end{abstract}

Kata kunci: Teknologi; Google Classroom; Gerak Parabola; Keterampilan Pemecahan Masalah. 


\section{PENDAHULUAN}

\section{Latar Belakang Masalah}

Kinematika diajarkan pada mata kuliah Fisika. Fisika adalah mata kuliah wajib diikuti oleh smua mahasiswa S1 dari jurusan Sistem Komputer di STMIK STIKOM Indonesia. Fisika berperan sebagai ilmu dasar mempunyai andil dalam pemgembangan ilmu-ilmu lain dan melatih berfikir logis dan matematis serta berada di depan dalam perkembangan teknologi yang dibutuhkan oleh Sistem Komputer. Berdasarkan observasi lapangan peneliti dalam proses pembelajaran dengan tatap langsung dengan mahasiswa, mahasiswa mengemukakan bahwa topik kinematika cukup sulit untuk dipelajari sehingga mahasiswa tidak tertarik dengan materi yang akan dipelajari. Selain itu mahasiswa juga mengemukakan keterampilan pemecahan masalah yang dimilikinya dirasakan sangat kurang sehingga siswa sulit terampil dalam memecahkan masalah yang diberikan. Karena alasan - alasan yang telah disebutkan di atas maka diperlukan suatu media pembelajaran fisika yang memungkinkan mahasiswa merasa nyaman dan aktif dalam mengkonstruksi pengetahuannya kapan saja dan dimana saja tanpa dibatasi ruang dan waktu.

\section{Rumusan Masalah}

Rumusan masalah dalam penelitian ini yaitu: Adakah perkembangan keterampilan pemecahan masalah mahasiswa topik kinematika pada pokok bahasan gerak parabola di Program Studi Sistem Komputer?.

\section{Kajian Teoritik}

Krulik dan Rudnik (dalam Slavin, 2000) mendefinsikan pemecahan masalah sebagai suatu usaha individu menggunakan pengetahuan, keterampilan dan pemahamannya untuk menemukan solusi dari suatu masalah. Menurut Polya (dalam Slavin, 2000) langkah-langkah penyelesaian masalah adalah memahami (understanding), merencanakan penyelesaian (planning), menyelesaikan masalah (solving) dan melakukan pengecekan kembali (checking). Sedangkan menurut Cooney (dalam Indrawati, 2014) pemecahan masalah adalah proses menerima masalah dan berusaha menyelesaikan masalah tersebut.
Menurut Slavin (2000), keefektifan pembelajaran dapat diukur menggunakan empat indikator sebagai berikut: (1) Kualitas pembelajaran yaitu seberapa besar kadar informasi yang disajikan sehingga siswa dengan mudah dapat mempelajarinya atau tingkat kesalahannya semakin kecil. Semakin kecil tingkat kesalahan yang dilakukan berarti semakin efektif pembelajaran, (2) Kesesuaian tingkat pembelajaran yaitu sejauh mana guru memastikan tingkat kesiapan siswa dalam menerima materi baru, (3) Insentif yaitu seberapa besar usaha guru memotivasi siswa untuk menyelesaikan atau mengerjakan tugas-tugas dan mempelajari materi yang diberikan. Semakin besar motivasi yang diberikan maka semakin besar pula keaktifan siswa dengan demikian pembelajaran akan efektif. (4) Waktu yaitu waktu yang dibutuhkan siswa untuk menyelesaikan kegiatan pembelajaran. Pembelajaran akan efektif apabila siswa dapat menyelesaikan pelajaran sesuai dengan waktu yang ditentukan.

Pada saat ini pembelajaran yang terpusat pada guru tidak lagi cocok pada generasi sekarang sehingga perlu berubah ke pendekatan yang lebih berpusat pada siswa yang amat beragam kemampuannya (Virdi. 2017.) Dewasa ini aplikasi Google Classroom memang telah digunakan dalam metoda pembelajaran di dunia barat sebagai penunjang dalam kegiatan pembelajaran dan bentuk support terhadap kemajuan teknologi saaat ini . Pengaplikasian Google Classroom sangat mudah digunakan dalam kegiatan pembelajaran bahkan di bulan Maret 2017 Google Classroom dapat diakses oleh semua orang melalui google pribadi. Aplikasi Google Classroom ini dapat diunduh secara gratis di perangkat berbasis android maupun $i O S$. Seperti yang telah diketahui bahwa kedua basis smartphone tersebut telah menjadi kebutuhan pokok di generasi 2019 ini. Beberapa fitur yang dapat dimanfaatkan guru pada Google Classroom adalah assignments, grading, communication, time-cost, archive course, mobile application dan privacy.

Adapun kelebihan Google Classroom yakni mudah digunakan, menghemat waktu, berbasis cloud, fleksibel, dan gratis (Iftakhar, 2016). Hal ini yang menjadi pertimbangan bahwa Google Classroom tepat digunakan dalam dunia 
pembelajaran. Penggunaan Google Classroom ini sesungguhnya mempermudah guru dalam mengelola pembelajaran dan menyampaikan informasi secara tepat dan akurat terhadap siswa (Hardiyana, 2015).

Melalui pembelajaran secara daring diharapakan dapat mengembangkan kemampuannya ke arah yang yang lebih baik. Salah satu kemampuan yang diharapkan dapat berkembang secara baik adalah kemampuan pemecahan masalah (Unaifah, 2014). . Kemampuan pemecahan masalah matematis adalah suatu keterampilan pada diri peserta didik agar mampu menggunakan kegiatan matematik untuk memecahkan masalah dalam matematik, masalah dalam ilmu lain dan dalam masalah kehidupan sehari-hari (Fadillah, 2009).

\section{Tujuan Penelitian}

Melalui pembelajaran secara online menggunakan Google Classroom maka tujuan pengembangan kelas virtual tersebut adalah mengembangkan keterampilan pemecahan masalah mahasiswa jurunsan sistem komputer dalam topik kinematika bahasan gerak parabola serta menguji efektivitas Google Classroom dalam proses pembelajaran untuk materi gerak parabola.

\section{METODE PENELITIAN}

Waktu dan Lokasi Penelitian

Waktu penelitian berlangsung dari bulan Januari sampai Agustus 2019 di jurusan Sistem Komputer STMIK STIKOM Indonesia.

\section{Rancangan Penelitian}

Penelitian ini menggunakan metoda penelitian Kuasi Eksperimen dengan menggunakan seluruh subjek dalam kelompok belajar (intact grup) untuk diberikan perlakuan (treatment) bukan menggunakan subjek secara acak (Mustaniroh, 2015). Penelitian Eksperimen adalah metoda penelitian yang dilakukan untuk mengetahui pengaruh pemberian suatu instrumen atas perlakuan terhadap subjek penelitian (Meika dkk, 2017).

\section{Teknik Pengumpulan Data}

Data dalam penelitian ini berupa hasil kerjaan mahasiswa dengan materi gerak parabola serta hasil dari kuesioner tertutup yang diberikan kepada mahasiswa melalui daring. Persoalan fisika yang diberikan kepada mahasiswa merupakan persoalan yang dapat meningkatkan kemampuan pemecahan dari mahasiswa yang bersangkutan.

\section{Metoda Analisis Data}

Secara umum data dianalisis secara deskriptif kualitatif yang didukung data kuantitatif untuk memperoleh gambaran tentang pengembangan keterampilan pemecahan masalah mahasiswa pada materi gerak parabola dengan langkah-langkah yang telah diuraikan (Slavin, 2000) serta melihat sejauh mana efektivitas Google Classroom tersebut dalam proses pembelajaran materi gerak parabola. Analisa data lapangan dilakukan untuk pengujian produk, menganalisis hasil pengujian serta membandingkan hasil pengujian dengan keadaan di lapangan.

\section{HASIL DAN PEMBAHASAN}

Kondisi awal mahasiswa sebelum memulai proses pembelajaran dengan menggunakan Google Classroom adalah siswa sangat mengalami kesulitan dalam menerapkan langkah-langkah pemecahan masalah terutama dalam topik gerak parabola. Hal tersebut dilihat berdasarkan observasi yang dilakukan oleh peneliti pada saat melaksanakan proses pembelajaran dengan cara tatap muka secara langsung di kelas, di mana mahasiswa mengemukakan bahwa topik parabola sangat sulit untuk dipelajari sehingga mahasiswa merasa tidak tertarik dengan materi yang akan dipelajari. Selain itu, mahasiswa juga mengemukakan bahwa keterampilan pemecahan masalah yang dimilikinya dirasakan sangat kurang sehingga mahasiswa sulit untuk terampil dalam memecahkan masalah yang diberikan. Oleh karena itu, peneliti melakukan perubahan metode pembelajaran yang akan diterapkan kepada mahasiswa. Cara yang dilakukan adalah melaksanakan proses pembelajaran materi gerak parabola dengan menggunakan Google Classroom.

Berdasarkan hasil penelitian, maka secara umum mahasiswa mengerjakan tes 1, 2 dan 3 dengan menggunakan langkah-langkah pemecahan masalah, di mana mahasiswa melakukan proses untuk memahami masalah (understanding), merencanakan penyelesaian 
(planning), menyelesaikan masalah (solving), melakukan pengecekan kembali (checking) (Gunawan dkk, 2018)

Terdapat mahasiswa yang mengerjakan tes secara runtut dimulai dari apa yang diketahui, apa yang ditanyakan, kemudian strategi yang diperlukan untuk memperoleh pemecahan masalah dari soal tes tersebut, kemudian siswa menyelesaikan masalah tersebut dan kemudian melihat kembali atau melakukan pengecekan. Berikut adalah soal tes 1, 2 dan tes 3 yang diberikan ke mahasiswa materi gerak parabola. Setelah soal diunggah ke Google Classroom maka mahasiswa mengerjakan soal-soal tes tersebut dan berikut contoh hasil pekerjaan dari 1 sampel mahasiswa dalam tes 1, 2 dan tes 3 .

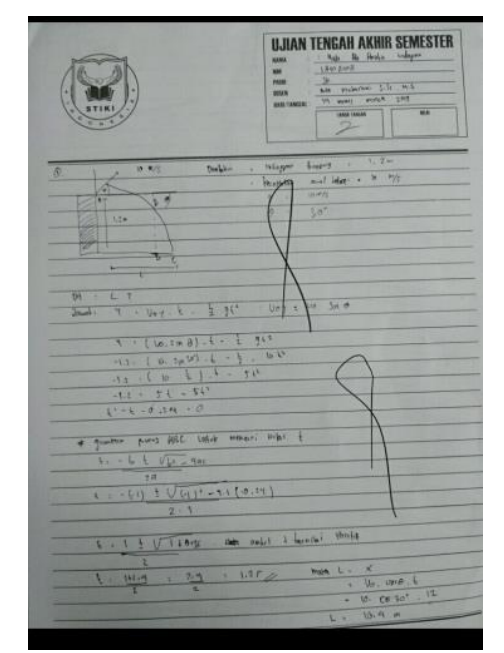

Gambar 1. Hasil evaluasi no.1

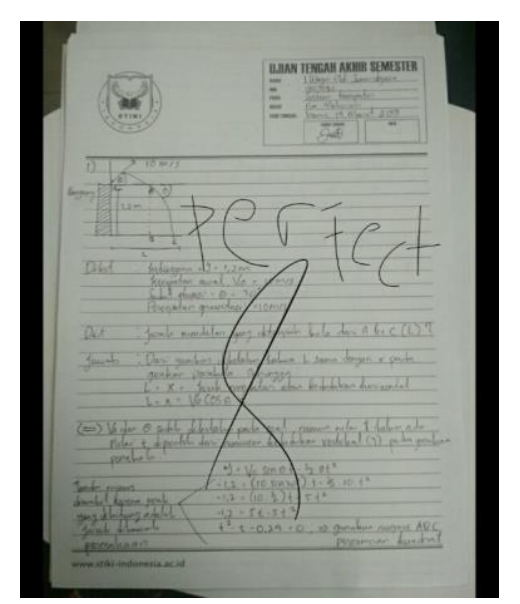

Gambar 2. Hasil evaluasi no.2

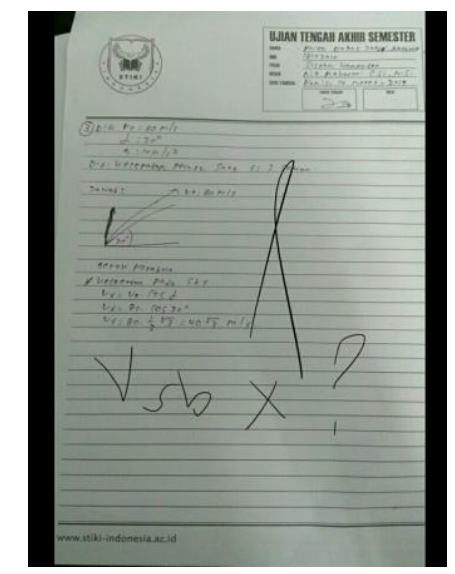

Gambar 3. Hasil evaluasi no.3

Gambar 1 merupakan hasil evaluasi no.1 kasus menentukan jarak mendatar yang ditempuh bola saat bola dilemparkan. Dari hasil tersebut dapat dilihat bahwa mahasiswa memulai langkah untuk menyelesaikan masalah dengan mengetahui terlebih dahulu apa yang dikemukakan di dalam soal, kemudian mahasiswa memahami apa yang ditanyakan dalam soal tersebut, kemudian mahasiswa mencari suatu cara/strategi yang dapat digunakan untuk memperoleh jawaban dari pertanyaan di dalam soal tersebut. Setelah itu, mahasiswa mencoba untuk menyelesaikan persoalan tersebut berdasarkan hal-hal yang telah diketahui, kemudian mahasiswa melakukan verifikasi atau pengecekan kembali hasil dari jawaban yang telah diperolehnya tersebut. Hal tersebut menunjukkan bahwa mahasiswa mengerjakan soal tes sesuai dengan langkah-langkah pemecahan masalah. Gambar 2 menunjukkan hasil evaluasi no. 2 kasus gerak parabola dalam menentukan jarak pada bidamg miring yang memiliki sudut tertentu. Dari hasil terlihat bahwa langkah-langkah penyelesaian kasus dimulai dari menuliskan besaran-besaran apa saja yang diketahui selanjutnya merumuskan apa yang ditanyakan lalu menuliskan rumus yang sesuai dengan apa yang ditanyakan serta melakukan perhitugan. Untuk gambar 3 merupakan hasil evaluasi no.3 untuk penyelesaian soal menentukan kecepatan peluru yang ditembakkan pada waktu tetentu. Dari hasil tersebut terlihat mahasiswa dapat menyelesaikan soal dengan baik dan benar hanya saja tidak mahasiswa tidak menuliskan sumbu x. Melalui Google Classroom, maka mahasiswa dapat belajar 
sendiri dari materi yang diunggah oleh pengajar dalam kelas Google Classroom yang telah dibuat. Dari materi tersebut, mahasiswa dapat menerapkan pengetahuannya tersebut untuk menyelesaikan persoalan fisika dalam tes yang diberikan sehingga mahasiswa telah mampu berpikir suatu cara yang tepat untuk digunakan dalam pemecahan masalah fisika melalui soal yang diberikan.

Keefektifan pembelajaran dengan menggunakan Google Classroom dapat dilihat berdasarkan tingkat kesalahan yang dibuat oleh mahasiswa saat menyelesaikan permasalahan yang diberikan, hal lain yang dapat menjadi acuan keefektifan pembelajaran adalah pada saat pengajar memotivasi mahasiswa untuk mempelajari materi yang telah diunggah ke dalam kelas Google Classroom melalui "Announcement" di kelas serta dosen memotivasi mahasiswa untuk mengerjakan soal tes dikarenakan mahasiswa mengemukakan bahwa soal tes yang diberikan sangat sulit, serta keefektifan pembelajaran tersebut dapat dilihat berdasarkan ketepatan waktu yang dipergunakan oleh mahasiswa untuk belajar, mengunggah hasil tes serta mengunggah hasil kuesioner melalui kelas Google Classroom. Selain itu keefektifan pembelajaran dengan menggunakan Google Classroom juga dapat dibandingkan dengan teori yang telah dikemukakan yaitu tingkat kesalahan yang dibuat oleh mahasiswa sangat kecil, . Oleh karena itu, dapat dilihat bahwa pembelajaran dengan menggunakan Google Classroom memiliki keefektifan dalam proses pembelajaran. Berikut adalah hasil kuesioner yang diunggah mahasiswa ke Google Classroom.

Dari hasil kuesioner yang diperoleh lebih dari $50 \%$ mahasiswa menyatakan bahwa pembelajaran melalui Google Classroom memiliki daya tarik sendiri karena dilakukan secara online, dan menyetujui bahwa Google Classroom membantu meningkatkan kemampuan pemecahan masalah karena bahan ajar sudah lengkap tersedia di Google Classroom dengan fitur-fitur yang dimilikinya sehinga meningkatkan minat dan motivasi mahasiswa untuk belajar lebih giat lagi pada materi gerak parabola yang dirasa rumit. Hampir lebih dari $60 \%$ mahasiswa menyetujui bahwa pembelajaran dengan Google Classroom dirasakan efektif karena proses pembelajaran bisa kapan saja dan dimana saja.
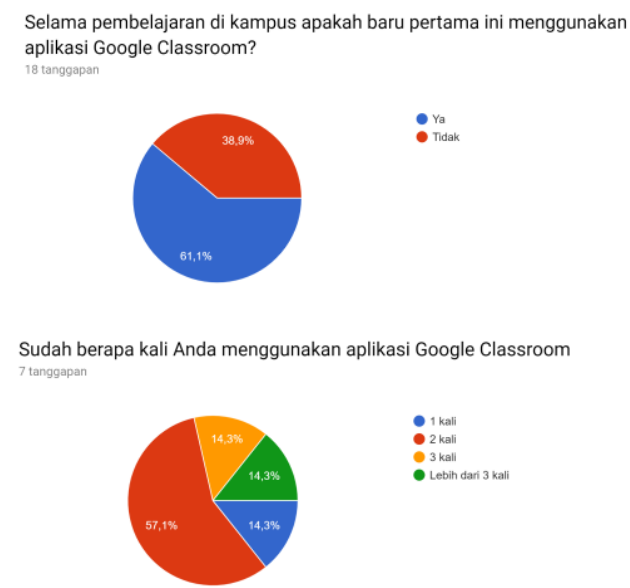

Pembelajaran melalui Google Classroom memiliki daya tarik tersendiri sebab pembelajaran dilakukan secara online
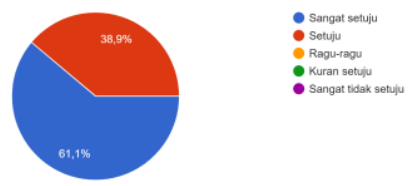

Apakah Google Classroom telah membantu meningkatkan kemampuan pemecahan masalah sebab materi belaj...telah ada di dalam kelas yang dibuat 18 tanggapan
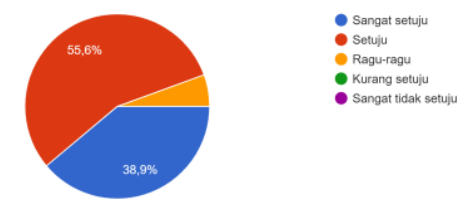

Pembelajan melalui Google Classroom efektif karena pembelajaran tidak hanya dilakukan di kelas, bisa di mana saja dan kapan saja
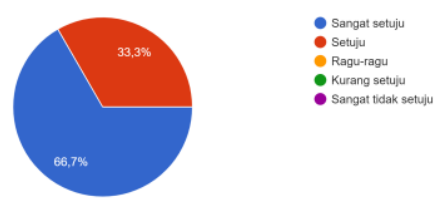

Gambar 4. Hasil pertanyaan kuesioner 5 
Fitur-fitur di Google Classroom apa sudah mendukung pembelajaran 18 tanggapan
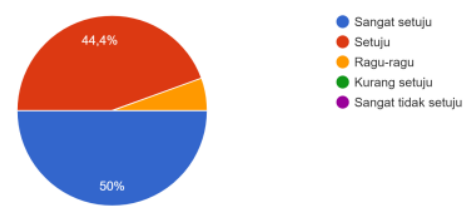

Gambar 5. Hasil pertanyaan kuesioner 6

Menurut anda, apa kekurangan selama menggunakan Google Classroom 18 tanggapan

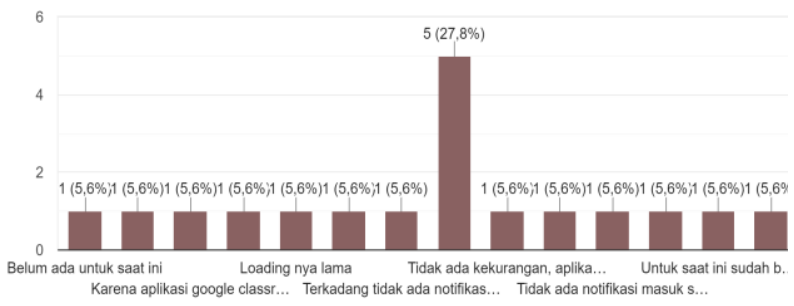

Gambar 6. Hasil pertanyaan kuesioner 7

Tabel 1. Hasil Evaluasi Mahasiswa

\begin{tabular}{|l|l|}
\hline Nama & Nilai \\
\hline I Komang Agus Wijaya Kusuma & 85 \\
\hline Putu Bagus Jaedy Anthony & 80 \\
\hline I Gusti Ngurah Yudha Andika & 90 \\
\hline I Made Restu Adi Darsana & 90 \\
\hline Ahmad Fauzi Febri & 100 \\
\hline Kadek Agitya Adi Pradana & 100 \\
\hline Joseph Ady Perwira & 100 \\
\hline I Wayan Juliantara & 85 \\
\hline I Kadek Yogha Astawa & 100 \\
\hline I Made Ade Pasetia Widnyana & 70 \\
\hline I Nyoman Wahyu Satria Wiguna & 100 \\
\hline I Wayan Adi Sumardiyasa & 100 \\
\hline Made Bayu Dwi Suputra & 100 \\
\hline I Kadek Wijawarsa & 100 \\
\hline I Gede Agus Andika & 80 \\
\hline
\end{tabular}

\begin{tabular}{|l|l|}
\hline I Kadek Dwi Chandra Putra & 75 \\
\hline I Gede Dharma Putra & 70 \\
\hline Kadek Ista Suryaduvta & 80 \\
\hline
\end{tabular}

Dari Tabel 1 terlihat hasil yang diperoleh mahasiswa nilai minimum diperoleh 70 dan nilai maksimum dengan rata-rata 89,166. Dari hasil evaluasi maka nilai mahasiswa dirujuk ke skor baku kampus STMIK STIKOM Indonesia seperti Tabel 2 dibawah ini.

Tabel 2. Skor Evaluasi

\begin{tabular}{|l|l|l|}
\hline Nilai Angka & Grade & Keterangan \\
\hline $80-100$ & A & Baik Sekali \\
\hline $65-<80$ & B & Baik \\
\hline $55-<65$ & C & Cukup \\
\hline $40-<55$ & D & Kurang \\
\hline $0-<40$ & E & Kurang Sekali \\
\hline
\end{tabular}

\section{KESIMPULAN}

Dengan menggunakan Google Classroom, maka kemampuan pemecahan masalah mahasiswa menjadi lebih baik. . Disamping itu keefektifan dari penggunaan Google Classroom dapat dilihat dari respon yang positif dari mahasiswa. Hal tersebut dapat disimpulkan dari hasil pekerjaan mahasiswa beserta jawaban mahasiswa dalam kuesioner tertutup yang diberikan secara daring. Selain itu, mahasiswa juga dapat menggunakan Google Classroom secara optimal dengan melalui proses belajar, proses untuk mengunggah hasil pekerjaan serta hasil kuesioner terbuka serta keefektifan proses pembelajaran dapat disimpulkan berdasarkan tingkat kesalahan yang dilakukan oleh mahasiswa saat mengerjakan soal tes, motivasi mahasiswa untuk belajar dan mengerjakan soal tes serta ketepatan waktu dari mahasiswa untuk menggunggah hasil tes dan hasil kuesioner. 


\section{DAFTAR PUSTAKA}

Fadillah, S (2009). Kemampuan Pemecahan Masalah Matematis dalam Pembelajaran Matematika. Seminar Nasional Penelitian, Pendidikandan Penerapan MIPA. Yogyakarta: Fakultas MIPA, Universitas Negeri Yogyakarta., 553-558.

Gunawan, F.I., Stefani, G.S. (2018). Pengembangan Kelas Virtual dengan Google Classroom dalam Keterampilan Pemecahan Masalah ( Problem Solving) Topik Vektor pada Siswa SMK Untuk Mendukung Pembelajaran. Seminar Nasional Pendidikan Matematika Etnomatnesia. 340-348.

Hardiyana, A. (2015) Implementasi Google Classroom sebagai Alternatif dalam Meningkatkan Mutu Pembelajaran di Sekolah. Karya Tulis Ilmiah, Cirebon : SMA Negeri $1 \quad$ Losari.

Iftakhar, S. (2016). Google Classroom : What Works and How ?. Jurnal of Education and Social Science, 2 (3) , 12-18.

Indarwati, D., Wahyudi, W., Ratu, N. (2014). Peningkatan Kemampuan Pemecahan Masalah Matematika melalui Penerapan Problem Based Learning untuk Siswa Kelas V SD. Satya Widya, 6 (1), 17- 27.

Meika, I., Sujana, A. (2017). Kemampuan Berpikir Kreatif dan Pemecahan Masalah Matematis Siswa SMA. Jurnal Penelitian dan Pembelajaran Matematika, 8 (2), 8-13.

Mustaniroh, S.A. (2015). Penerapan Google Classroom sebagai Media Pembelajaran pada Pelajaran Kimia di SMK Negeri 2 Temanggung. Artikel Ilmiah, Salatiga : Fakultas Teknologi Informasi. Universitas Kristen Satya Wacana.

Slavin, R. (2000). Educational Phsyscology : Theory and Practice. New Jersey : Pearson Education.

Unaifah, F., Suprapto, N. (2014). Profil Kemampuan Pemecahan Masalah dan Hasil Belajar Siswa pada Materi Elastisitas ditinjau dari Gaya Belajar (Learning Style). Jurnal Inovasi
Pendidikan Fisika, 3(2), 27-32Viridi, S., Viridi, S., Halid, J., Kristianti, T. (2017). Penelitian Guru untuk Mempersiapkan Generasi $\mathrm{Z}$ di Indonesia. SEAMEO QITEP in Science. Bandung: P4TK IPA. 1- 